\begin{tabular}{r|l|l|l}
$\begin{array}{r}\text { Case Reports in } \\
\text { Gastruenterology }\end{array}$ & $\begin{array}{l}\text { Case Rep Gastroenterol 2010;4:498-501 } \\
\text { DOI: 10.1159/000321158 }\end{array}$ & $\begin{array}{l}\text { Published online: } \\
\text { November 3, 2010 }\end{array}$ & $\begin{array}{l}\text { O 2010 S. Karger AG, Basel } \\
\text { ISSN 1662-0631 } \\
\text { www.karger.com/crg }\end{array}$ \\
\hline
\end{tabular}

\title{
Right Ventricular Pneumocardia Secondary to Hepatic Abscesses
}

\author{
Matthew Tichauera, b Sujit V. Sakpal ${ }^{\mathrm{a}}$ \\ Ronald S. Chamberlain ${ }^{\mathrm{a}-\mathrm{c}}$ \\ ${ }^{a}$ Department of Surgery, Saint Barnabas Medical Center, Livingston, N.J., USA; \\ bSt. George's University School of Medicine, St. George's, Grenada; 'Department \\ of Surgery, University of Medicine and Dentistry of New Jersey, Newark, N.J., USA
}

\section{Key Words}

Pneumocardia $\cdot$ Hepatic abscess $\cdot$ Right ventricle $\cdot$ Clostridium perfringens

\begin{abstract}
Gas-filled abscesses and gas gangrenes are extremely rare causes of intrahepatic gas. Even rarer, however, is the occurrence of gas within the non-portal hepatic veins. Most often seen in diabetic patients, dissemination and hepatic seeding of bacteria has been linked to procedures such as femoral catheters as well as liver lacerations and pyelonephritis. We report the case of a 69 -year-old relatively healthy male who presented to our emergency department with abdominal pain and a fever of $103.3^{\circ} \mathrm{F}$ $\left(39.6^{\circ} \mathrm{C}\right)$. A contrast-enhanced computed tomography scan of the abdomen revealed multiple hepatic abscesses and gas within the hepatic venous system as well as pneumocardia. In conclusion, gas within the non-portal hepatic veins is usually an indication of a serious underlying condition and its immediate identification is essential for treatment as hematogenous dissemination has already begun.
\end{abstract}

\section{Introduction}

Gas-filled abscesses and gas gangrenes are extremely rare causes of intrahepatic gas. Infrequently clostridial species may be the cause of intrahepatic air, and this is seen most commonly in diabetic patients [1-3]. Even rarer, however, is the finding of gas within the hepatic veins (non-portal) due to rupture of hepatic abscesses. The clostridial species, specifically C. perfringens, is responsible for many of the various histotoxic syndromes seen in patients with sepsis and infection. Fulminant infections such as gas gangrene, food poisoning, and enteritis necroticans are caused by the production and release of volatile fatty acids, hydrogen, and nitrogen gas from the Clostridium organism. In addition to C. perfringens, $C$. septicum is the organism responsible for non-traumatic, spontaneous gas gangrene which is most often found in the colon. The clostridial species has been implicated in studies involving hepatic venous air [4]. Additionally, non-portal, hepatic

Ronald S. Chamberlain, MD, MPA, FACS
Department of Surgery, Saint Barnabas Medical Center

94 Old Short Hills Rd., Livingston, NJ 07039 (USA)

Tel. +1 973 322 5195, Fax +1 973322 2471, E-Mail rchamberlain@sbhcs.com 


\begin{tabular}{r|l|l|l}
$\begin{array}{r}\text { Case Reports in } \\
\text { Gastruanteriology }\end{array}$ & $\begin{array}{l}\text { Case Rep Gastroenterol 2010;4:498-501 } \\
\text { DOI: 10.1159/000321158 }\end{array}$ & $\begin{array}{l}\text { Published online: } \\
\text { November 3, 2010 }\end{array}$ & $\begin{array}{l}\text { O 2010 S. Karger AG, Basel } \\
\text { ISSN 1662-0631 } \\
\text { www.karger.com/crg }\end{array}$ \\
\hline
\end{tabular}

venous air has been reported in patients with bowel ischemia, emphysematous pyelonephritis, manipulation of tunneled femoral catheters, and liver lacerations secondary to blunt abdominal trauma [5-8].

\section{Case Report}

A 69-year-old man with gastroesophageal reflux disease and diverticulosis presented to our emergency department hemodynamically stable with a two-day history of generalized weakness, chills, epigastric pain, and a fever of $103.3^{\circ} \mathrm{F}\left(39.6^{\circ} \mathrm{C}\right)$, one week after undergoing a routine colonoscopy. On physical examination, a moderately distended abdomen with mildly tender hepatomegaly was noted. Relevant laboratory investigation revealed a leukocytosis $(16,400 / \mu \mathrm{l})$ with $21 \%$ bands, elevated liver function tests [total bilirubin $2.2 \mathrm{mg} / \mathrm{dl}(0.1-1.2 \mathrm{mg} / \mathrm{dl})$, aspartate transaminase $124 \mathrm{IU} / \mathrm{l}(5-40 \mathrm{IU} / \mathrm{l})$, alanine transaminase $242 \mathrm{IU} / \mathrm{l}(7-56 \mathrm{IU} / \mathrm{l})$ and serum lipase $283 \mathrm{U} / \mathrm{l}(7-60 \mathrm{U} / \mathrm{l})$ ]. Urinalysis showed proteinuria, ketonuria, and hyaline casts. The patient was administered broad-spectrum antibiotics, piperacilling and tazobactam, empirically.

An ultrasound of the abdomen showed areas of increased echogenicity with lobular contours ( $3.4 \mathrm{~cm}$ in diameter) in the posterior sector of the right lobe of the liver. A contrast-enhanced computed tomography (CT) revealed multiple hepatic abscesses as well as air within the hepatic venous system (fig. 1) and the right ventricle (ig. 2).

The patient became hemodynamically unstable and did not respond to aggressive resuscitative efforts, including high-flow oxygen therapy. Thereafter, his general condition rapidly worsened, and despite all measures, the patient expired. Blood cultures subsequently grew C. perfringens within $24 \mathrm{~h}$. An autopsy was denied by the family.

\section{Discussion}

Gas within the hepatic venous system was initially reported on an ultrasound examination in 1989. The case involved a patient with a diagnosis of emphysematous pyelonephritis [7]. Since then, rare anecdotal cases have been published and each of these reports has postulated theories relating to the mechanism by which gas enters the hepatic venous system [5-8].

The first such theory was described by James et al. [7] and involved a patient suffering from emphysematous pyelonephritis. The authors contend that hepatic venous air was a transient phenomenon in which gas entered the inferior vena cava via the renal vein and subsequently entered the hepatic vein. Chen et al. [6] described a patient with a similar condition and proposed that hepatic venous gas developed from fermentation of glucose. The authors reasoned that the formation and diffusion of gas into the vasculature required four major factors, which included: (1) the presence of gas-forming bacteria, (2) a high tissue glucose level, (3) impaired tissue perfusion, and (4) a defective immune response. As a result of anaerobic glucose metabolism, hydrogen and carbon dioxide gases are produced as byproducts and can enter the hepatic venous circulation. Poor tissue perfusion contributes to the accumulation of these gases within the tissue with eventual diffusion into the bloodstream. Brown et al. [8] reported a case of hepatic venous gas in a patient suffering from blunt abdominal trauma. They postulated that the sudden increase in intraabdominal pressure, caused by the impact, forced intraabdominal air into the bowel wall. The gas was then absorbed into the portal circulation and passed into the hepatic veins via sinusoids. Finally, Marin et al. [5] described a case of direct entry of air from the inferior vena cava via the femoral vein that occurred during manipulation of a 


\begin{tabular}{r|l|l|l}
$\begin{array}{r}\text { Case Reports in } \\
\text { Gastruenterology }\end{array}$ & $\begin{array}{l}\text { Case Rep Gastroenterol 2010;4:498-501 } \\
\text { DOI: 10.1159/000321158 }\end{array}$ & $\begin{array}{l}\text { Published online: } \\
\text { November 3, 2010 }\end{array}$ & $\begin{array}{l}\text { O 2010 S. Karger AG, Basel } \\
\text { ISSN 1662-0631 } \\
\text { www.karger.com/crg }\end{array}$ \\
\hline
\end{tabular}

tunneled femoral catheter. Other potential explanations for gas entry into the hepatic veins include the dilatation and engorgement of the vasculature seen in right-sided heart failure or a portal vein-to-hepatic vein fistula [9].

In our patient, we believe that gas-producing anaerobic bacteria most likely gained access to the liver from a colonic diverticular microperforation via the portal circulation. Following seeding of the liver, production of toxins by the clostridial species resulted in the formation of intrahepatic abscesses with rupture into an adjacent hepatic vein and ultimately a right ventricular pneumocardia. Unfortunately, the highly aggressive nature of the offending microorganism caused overwhelming bacteremia and the patient developed septic shock. Following these developments, all treatment efforts were rendered futile.

As discussed above, gas within the non-portal hepatic venous system may arise due to several etiologies. Although in most cases the condition has been reported as an incidental radiological finding, it is usually an indication of a serious underlying condition that is its cause. Hence, immediate identification of the underlying etiology is essential and the treatment should be directed towards it $[1,6]$. A CT scan of the abdomen and pelvis as well as a thorough workup did not reveal a mechanical cause for this case and thus it is not possible to identify the origin of the organisms causing the hepatic abscesses. A focused assessment along with immediate administration of empiric antibiotics following presentation to the emergency department may avert progression of this condition as the presence of gas in the hepatic vein is of paramount importance should it be related directly to an infectious etiology, and as delay in treatment may permit further bacterial dissemination [1].
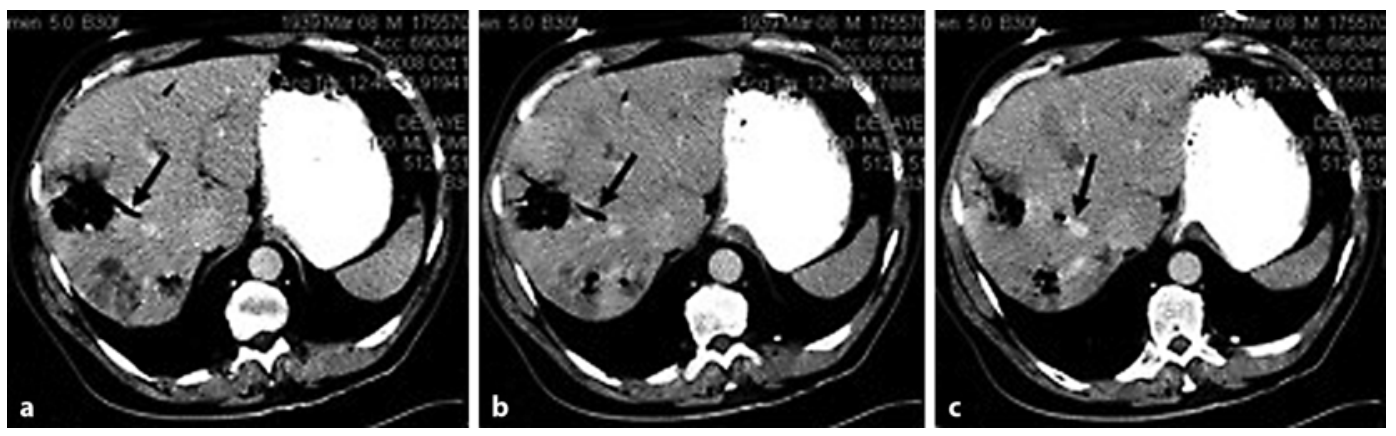

Fig. 1. Contrast-enhanced CT scan of the abdomen. Multiple abscesses in the right lobe of the liver and gas (arrows) coursing through the anterior sectoral branch of the right hepatic vein (sequential images a to c) which lies adjacent to the hepatic abscess. $\mathbf{c}$ The gas coursing towards the inferior vena cava is clearly shown. 


\begin{tabular}{r|l|l|l} 
Case Reports in & $\begin{array}{l}\text { Case Rep Gastroenterol 2010;4:498-501 } \\
\text { DOI: 10.1159/000321158 }\end{array}$ & $\begin{array}{l}\text { Published online: } \\
\text { November 3, 2010 }\end{array}$ & $\begin{array}{l}\text { ○ 2010 S. Karger AG, Basel } \\
\text { ISSN 1662-0631 } \\
\text { www.karger.com/crg }\end{array}$ \\
\hline
\end{tabular}

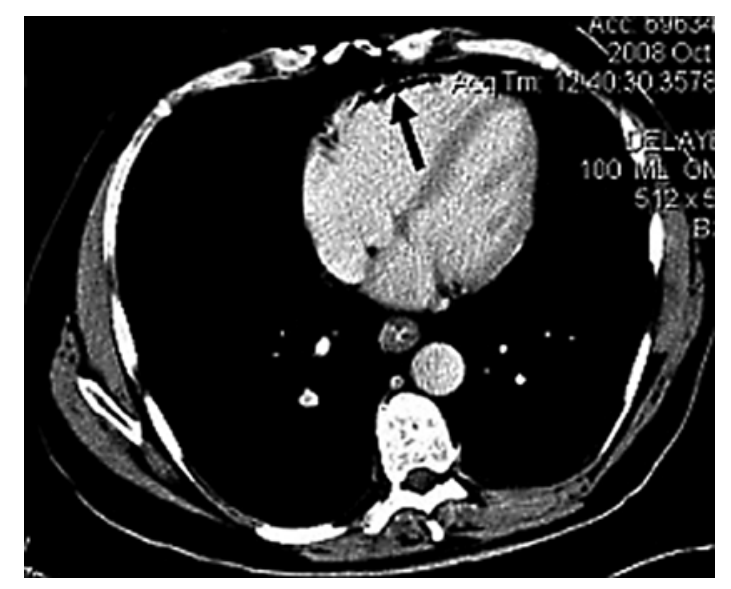

Fig. 2. Contrast-enhanced CT scan of the chest demonstrating air (arrow) within the right ventricle.

\section{References}

1 Foster SC, Schneider B, Seaman WB: Gas-containing pyogenic intra-hepatic abscesses. Radiology 1972;94: 613-618.

-2 Elson MW: Antemortem radiographic demonstration of gas gangrene of the liver. Radiology 1960;74:57-60.

3 Thorley LG, Figiel LS, Figiel SJ: Roentgenographic findings in accidental ligation of the hepatic artery. Radiology 1965;85:56-58.

4 Wise SW, Labuski MR: Infected hepatic infarction: an unusual cause of portal venous gas. Emerg Radiol 1999;6:367-369.

5 Marin B, Chouvy V, Denier M, Debard I, Tran-Minh V: Gas in hepatic veins associated with tunneled femoral hemodialysis catheter. J Radiol 2002;83:47-48.

6 Chen KW, Huang JJ, Wu MH, Lin XZ, Chen CY, Ruaan MK: Gas in hepatic veins: a rare and critical presentation of emphysematous pyelonephritis. J Urol 1994;151:125-126.

7 James PNZ, Chalmers AG, Fowler RC: Ultrasound demonstration of gas in hepatic veins. Clin Radiol 1989;40:429-430.

8 Brown MA, Hauschildt JP, Casola G, Gosink BB, Hoyt DB: Intravascular gas as an incidental finding at US after blunt abdominal trauma. Radiology 1999;210:405-408.

-9 Kriegshauser JS, Reading CC, King BF, Welch TJ: Combined systemic and portal venous gas: sonographic and CT detection in two cases. AJR Am J Roentgenol 1990;154:1219-1221. 